\title{
Reproductive and Child Health Related Contents at undergraduate medical level in the Community Medicine-- Teachers' view
}

\author{
Dr. Sharmin Jahan ${ }^{1}$,Dr. Md. Humayun Kabir Talukder ${ }^{2}$ \\ ${ }^{1}$ Assistant Professor, Department of Community Medicine, Dhaka National Medical College, Dhaka, ${ }^{2}$ Associate Professor \\ (Teaching Methodology) \& Course Coordinator, Centre for Medical Education (CME), Mohakhali, Dhaka.
}

\begin{abstract}
Objectives: The objectives of this study were to assess the views of teachers regarding the reproductive and child health related contents at the medical undergraduate level in Bangladesh.

Methodology: A descriptive type of cross-sectional study was carried out from January 2009 to June 2009 among 30 teachers of government and non government medical colleges in Bangladesh. Data were collected by pre tested self administered semi-structured questionnaire.

Results: Results of the study shows that a total of $58 \%$ of the teachers feel that topics such as maternal health, infant and child care, family planning and adolescent health might be useful in future life. They have shown more interest towards problem solving class with scenario exercises, group discussions and brain storming sessions. They also feel that clinical oriented topics should be included more. It was also revealed that more than $65 \%$ of the teachers feel that $\mathrm{RCH}$ related contents are the most important or one of the most important topics in the Community Medicine.

Conclusion and recommendation: Some of the non-traditional teaching methods like problem solving class with scenario exercises, group discussions and brain storming sessions may be practiced to improve the teaching and assessment in reproductive and child health related contents at the undergraduate medical level in Bangladesh.
\end{abstract}

Key words: medical education, teachers' views, Reproductive and Child Health related contents

\section{Introduction:}

Medical education has entered a new era at all levels. Medical educators are seeking for an answer to what changes are necessary to prepare future physicians for practice. Reproductive and Child Health is an important part of the Community Medicine that is developing day by day. The concept of teachinglearning as well as the assessment system is also changing in the field of Reproductive and Child Health.

There is a great responsibility of medical educators to train physicians to improve the sexual and reproductive health of their communities. Sexual and reproductive health care is under-represented in the basic educational curriculum for medical professionals ${ }^{1}$. Not only that, Professor Sunder Lal and B.M. Vashisht feel that there is inadequacy in audiovisual aids, computers and insufficient staffs ${ }^{2}$.

For ensuring the quality of services and client satisfaction teaching of Community Medicine is the prime concern. Medical students should deal with the clients and community. Quality of Reproductive and Child Health services is ensured when all the specific needs are accessible and available for effective utilisation by the clients. Quality of antenatal care, safe delivery, postnatal care, neonatal care, immunisation, management of diarrhoea and acute respiratory infections are ensured after skill education in undergraduate level ${ }^{3}$.

All the Medical colleges of Bangladesh are performing their teaching, training and research programmes as a part of their course. So there is an opportunity of incorporating newer strategies of reproductive and child health into the curriculum without any extra time requirement.

\section{Materials \& Methods}

This descriptive type of cross-sectional study was carried out from January 2009 to June 2009 among 30 teachers. The study was done in 2 Government and 2 private medical colleges in Dhaka city. The study included teachers like Professors, Associate Professors and Assistant Professors of different medical colleges who teach Community Medicine and the lecturer who has MPH post graduation degree in the Community Medicine. Data were collected by self administered 
J. Dhaka National Med. Coll. Hos. 2012; 18 (01): 29-33 semi-structured Questionnaire. Each college was corresponded officially. Prior appointment was taken from faculties of Department of Community Medicine. The Questionnaire was given to teachers.

\section{Results}

Table 1 Distribution of the respondents by designation.

\begin{tabular}{|c|c|c|}
\hline $\begin{array}{l}\text { Designation } \\
\text { respondents }\end{array}$ & Frequency & Percentage \\
\hline Professor & 7 & 23.33 \\
\hline Associate Professor & 4 & 13.33 \\
\hline Assistant Professor & 5 & 16.67 \\
\hline Lecturer & 14 & 46.67 \\
\hline Total & 30 & 100.0 \\
\hline
\end{tabular}

Table 1 shows the frequency distribution of the respondents by their designation.

Table 2 Distribution of the opinion of respondents regarding the usefulness of various RCH related contents

\begin{tabular}{|c|c|c|}
\hline \multirow{2}{*}{$\begin{array}{l}\text { Usefulness of } \mathrm{RCH} \\
\text { related content in future }\end{array}$} & \multicolumn{2}{|c|}{ Teachers, $(n=30)$} \\
\hline & $\begin{array}{l}\text { Interesting } \\
(\%)\end{array}$ & $\begin{array}{l}\text { Useful in } \\
\text { future }(\%)\end{array}$ \\
\hline Family Planning & $20(15.3)$ & $19(14.5)$ \\
\hline Maternal Health & $23(17.6)$ & $21(16.0)$ \\
\hline Infant and Child Care & $24(18.3)$ & $19(14.5)$ \\
\hline $\begin{array}{l}\text { Male participation \& male } \\
\text { responsibilities }\end{array}$ & $10(7.6)$ & $12(9.2)$ \\
\hline Adolescent health & $14(10.7)$ & $18(13.7)$ \\
\hline Infertility & $3(2.3)$ & $6(4.6)$ \\
\hline RTI/STD and HIV/AIDS & $5(3.8)$ & $11(8.4)$ \\
\hline $\begin{array}{l}\text { Screening or reproductive } \\
\text { health condition }\end{array}$ & $2(1.5)$ & $10(7.6)$ \\
\hline $\begin{array}{l}\text { Immunization of children } \\
\text { in the community }\end{array}$ & $14(10.7)$ & $6(4.6)$ \\
\hline Breast Feeding & $8(6.1)$ & $3(2.3)$ \\
\hline Demography & $8(6.1)$ & $4(3.1)$ \\
\hline Miscellaneous & - & $2(1.5)$ \\
\hline
\end{tabular}

* Number of frequency is more than $100 \%$ due to multiple responses.

n=Total number of respondents.

It has been observed that $24(18.3 \%)$ teachers feel interest about infant and child care, 23 (17.6\%) feel interest about maternal health, 20 (15.3\%) about family planning and $14(10.7 \%)$ is interested about adolescent health and immunization. Although it has been observed that $21(16.0 \%)$ teachers feel maternal health, 19 (14.5\%) feel interest about infant and child care and family planning and $18(13.7 \%)$ in adolescent health and $12(9.2 \%)$ think that male participation \& male responsibilities might be useful in future life.
Table 3 Distribution of the respondents about their interest in different kinds of teaching methods along with the teaching methods which are not usually practiced in the classroom

\begin{tabular}{lll}
\hline $\begin{array}{l}\text { Different teaching } \\
\text { methods }\end{array}$ & $\begin{array}{l}\text { Teachers } \\
\text { Interesting } \\
\text { teaching } \\
\text { methods } \\
(\%)\end{array}$ & $\begin{array}{l}\text { Not } \\
\text { usually } \\
\text { practiced } \\
(\%)\end{array}$ \\
\hline Lectures class & $26(21.0)$ & $\begin{array}{l}\text { (2.7) } \\
\text { Problem solving }\end{array}$ \\
$\begin{array}{l}\text { with scenario exercise } \\
\text { Tutorials }\end{array}$ & $18(14.5)$ & $5(4.5)$ \\
Brain storming session & $17(13.7)$ & $21(18.9)$ \\
Group discussion & $23(18.5)$ & $14(12.6)$ \\
Class room exercise & $13(10.5)$ & $12(10.8)$ \\
Role play & $4(3.2)$ & $19(17.1)$ \\
Short presentation & $8(6.5)$ & $18(16.2)$ \\
\hline
\end{tabular}

* Number of frequency is more than $100 \%$ due to multiple responses.

Table 4 Percentage frequency of the respondents whether they want any reform in the lecture classes

\begin{tabular}{lll}
\hline Subjects of opinion & $\begin{array}{l}\text { Teachers } \\
\text { Frequency }\end{array}$ & Percentage \\
\hline $\begin{array}{l}\text { Decrease the number } \\
\text { of lecture classes }\end{array}$ & 7 & 8.1 \\
$\begin{array}{l}\text { Increase the number of } \\
\text { lecture classes }\end{array}$ & 12 & 14.0 \\
$\begin{array}{l}\text { Include more clinical } \\
\text { oriented topics }\end{array}$ & 16 & 18.6 \\
$\begin{array}{l}\text { Make use of } \\
\text { audiovisual aids }\end{array}$ & 34 & 39.6 \\
$\begin{array}{l}\text { Only important topics } \\
\text { to be discussed }\end{array}$ & 12 & 14.0 \\
$\begin{array}{l}\text { Good as they are } \\
\text { Miscellaneous }\end{array}$ & 3 & 3.5 \\
\hline
\end{tabular}

\section{* Number of frequency is more than $100 \%$ due to multiple responses.}

Table 3 shows that teachers have shown more interest towards some of the non-traditional teaching methods like problem solving class with scenario exercises, group discussions and brain storming sessions. Although they have also noted that these methods are not usually practiced in our country.

Table 4 shows the respondent's responses regarding reformation of the lecture classes. It has been revealed 
J. Dhaka National Med. Coll. Hos. 2012; 18 (01): 29-33 that most of the teachers have demanded more use of audiovisual aids. They also feel that clinical oriented topics should be included more.

Table 5 Percentage frequencies of the respondents about their opinion related to reform in the tutorial and practical classes

\begin{tabular}{lll}
\hline \multicolumn{1}{c}{ Subjects of opinion } & $\begin{array}{l}\text { Teachers } \\
\text { Tutorial } \\
\text { Class (\%) }\end{array}$ & $\begin{array}{l}\text { Practical } \\
\text { Class (\%) }\end{array}$ \\
\hline $\begin{array}{l}\text { Decrease the number } \\
\text { of classes }\end{array}$ & $6(6.7)$ & $8(11.0)$ \\
$\begin{array}{l}\text { Increase the number of } \\
\text { classes }\end{array}$ & $16(17.8)$ & $13(17.8)$ \\
$\begin{array}{l}\text { Include more clinical } \\
\text { oriented topics }\end{array}$ & $20(22.2)$ & $16(21.9)$ \\
$\begin{array}{l}\text { Introduce } \\
\text { discussion group }\end{array}$ & $25(27.8)$ & $16(21.9)$ \\
$\begin{array}{l}\text { Make } \\
\text { audiovisual aids and } \\
\text { models }\end{array}$ & $16(17.8)$ & $16(21.9)$ \\
Miscellaneous & $7(7.8)$ & $4(5.5)$ \\
\hline
\end{tabular}

\section{* Number of frequency is more than $100 \%$ due to multiple responses}

Table 5 shows that the teachers have proposed to introduce group discussion (27.8\%) and more clinical oriented topics $(22.2 \%)$ in the lecture and practical classes. They have also urged to increase more number of practical and tutorial classes. As for using of audiovisual aids and models in the classes, they have also shown good interest.

Table 6 Depicting the comparison of distribution of the respondents whether they want to add any of the following part as regular teaching

\begin{tabular}{l|l}
\hline Topic of opinion & $\begin{array}{l}\text { Percentage of the } \\
\text { respondents }\end{array}$ \\
\hline Student's seminar & $34.80 \%$ \\
Group discussion & $31.90 \%$ \\
Clinical studies and & $26.40 \%$ \\
treatment & $06.90 \%$ \\
others & $\mathbf{1 0 0 \%}$ \\
Total & \\
\hline
\end{tabular}

The above table reveals that most of the teachers feel that students' seminar, group discussion and case studies and treatment might be effective if they are added as part of regular teaching. Many of the teachers $(34.75 \%)$ have chosen for students' seminar as part of regular teaching.

\section{Distribution of evaluation of $\mathrm{RCH}$ related content}

by the respondents

\begin{tabular}{ll}
\hline RCH related content & Teachers (\%) \\
\hline Useless altogether & $2(7.7)$ \\
& \\
$\begin{array}{l}\text { Only theoretical, less practical subjects } \\
\text { for practical use }\end{array}$ & $7(26.9)$ \\
$\begin{array}{l}\text { Not responding } \\
\text { Most important, above all topics in the }\end{array}$ & $9(15.4)$ \\
Community Medicine & $9(34.6)$ \\
One of the few most important & $8(30.8)$ \\
Total & 30 \\
\hline
\end{tabular}

Table 7 reveals that more than $65 \%$ of the teachers feel that $\mathrm{RCH}$ related contents are the most important or one of the most important topics in Community Medicine although $7.70 \%$ of the teachers believe that this $\mathrm{RCH}$ related contents are of no useful at all.

Some suggestions made by the teachers to improve the teaching learning tools and methods at the undergraduate level (according to the respondents' choices)

1. The syllabus of RCH related content should be shortened and there should be addition of more clinical oriented topics.

2. More use of audio visual aids to understand the $\mathrm{RCH}$ related contents.

3. Addition of group discussion, seminar etc.

4. More field visit related to $\mathrm{RCH}$ related contents is needed.

5. $\quad \mathrm{RCH}$ related classes should be more enjoyable through introduction of new teaching learning tools.

\section{Discussion}

Most of the teachers (45\%) feel interest about infant and child care, maternal health and family planning. Some of the teachers $(22.90 \%)$ have shown their concern and interest about adolescent health and male participation \& male responsibilities. Haselgrave and Olatunbosun feel that insufficient attention has been paid to instruction in adolescent health in medical schools, particularly in developing countries, where a much higher proportion of population is under the age of 25. Students should be taught that young men and women face specific social and economic pressures, which can have adverse effects to sexuality and reproductive issues ${ }^{1}$.

Teachers have shown more interest towards some of the non-traditional teaching methods like problem 
J. Dhaka National Med. Coll. Hos. 2012; 18 (01): 29-33 solving class with scenario exercises, group discussions and brain storming sessions. They have also noted that these methods are not usually practiced in our country. Moreover, most of the teachers have demanded more use of audiovisual aids. Many of the teachers $(34.80 \%)$ have chosen for students' seminar as part of regular teaching. It is increasingly important for us to incorporate some innovative educational methods and tools. Problem solving exercise may be a major part of learning process. This will provide opportunity for developing processed thinking for analyses, taking decision and executing the appropriate activity $^{4}$. Group discussion allows everyone to participate in an active process. It will provide for greater interaction between teacher and students. Brainstorming is a useful tool that can be used to develop highly creative solutions to a problem. Students learn best when they are actively involved in the process. Researchers found that, students working in small groups can learn more and retain it longer than when the same content is presented in other instructional formats ${ }^{5}$.

No single teaching or learning tool has been shown such that it can be mentioned specifically rather it is almost clear that every single tool is more or less considered as effective tool in the teaching and learning of $\mathrm{RCH}$ related contents.

It is also revealed that more than $65 \%$ of the teachers feel that $\mathrm{RCH}$ related contents are the most important or one of the most important topics in Community Medicine, although $7.70 \%$ of the teachers believe that this $\mathrm{RCH}$ related contents are of no useful at all. It is of no doubt that reproductive and child health is an important part of general health that needs universal concern. It is very important for women during their reproductive years because much reproductive health related problems arise during this period. Any failures in living a healthy reproductive life shall lead to different sexual diseases and other deficiencies that could also cause a risk to the life of a woman. Usually two groups of every society need special attention, women during the period of their pregnancy and children particularly during their infancy. Special care of a pregnant woman has double health benefit: first, to her as a member of society. Impairment of women's health has adverse effect on the health of other family members. Secondly, for the health of her child ${ }^{6}$. It is hopeful that most of the teachers can realise the importance of reproductive and child health.

\section{Conclusions}

The present study on the views of teachers regarding $\mathrm{RCH}$ related contents revealed that more than half of the teachers feel that topics such as maternal health, infant and child care, family planning and adolescent health might be useful in future life. Teachers have shown more interest towards some of the nontraditional teaching methods like problem solving class with scenario exercises, group discussions and brain storming sessions. And they have noted that these methods are not usually practiced in our country. Most of the teachers have demanded more use of audiovisual aids. They also feel that clinical oriented topics should be included more. Many of the teachers have chosen for students' seminar as part of regular teaching. About two-thirds of the teachers feel that $\mathrm{RCH}$ related contents are the most important or one of the most important topics in Community Medicine. Only $7.70 \%$ of the teachers believe that this $\mathrm{RCH}$ related contents are of no useful at all.

The understanding developed from the above findings and the contemporary ideas and trends in $\mathrm{RCH}$ related contents in the developed world can be integrated in order to plan for improving the methods of teaching and assessment in Reproductive and Child Health in Bangladesh.

\section{Acknowledgement}

I am grateful to all the Heads of the Department of Community Medicine and Principals of Bangladesh Medical College, Dhaka National Medical College, Dhaka Medical College, Ibrahim Medical College and Sir Salimullah Medical College for kindly cooperating for conducting this study smoothly.

\section{References}

1. Haslegrave M and Olatunbosun O. Incorporating sexual and reproductive health care in the medical curriculum in developing countries. 2003 Reproduct Health Matters. 2003;11(21):49-58.

2. Lal S, Vashisht BM; Orientation of Faculty of Medical Colleges in $\mathrm{RCH}$ Programme by Indian Association of Preventive and Social Medicine. Indian $\mathrm{J}$ of Com Med. 2003; 28(4). Available from: http://www.indmedica.com/journals.php. [Accessed 4 Jun 2009].

3. Lal S. Strategies of Incorporating $\mathrm{RCH}$ Strategies and Newer Develpments into Curriculum to Enrich TeachingTraining and Research Programme of Community Medicine. Indian J of Com Med. 2001; 26(3)Editorial. Available from: http://www.indmedica.com/journals.php[Accessed 14 Jun 2009].

4. Norris J. Richard, Larke Alvin, Briers E. Gary. Selection of Student Teaching Centers and Cooperating Teachers in 
J. Dhaka National Med. Coll. Hos. 2012; 18 (01): 29-33 Agriculture and Expectations of Teacher Educators Regarding These Components of a Teacher Education Program: A National Study .Texas A\&M University.

5. Uddin MM. 2009. Trends in the Presentation of Developmental Anatomy and Genetics in the Contemporary Developmental Anatomy Books and Their Reflections in the Written Assessment at the Medical Undergraduate Level in Bangladesh. Thesis (M. Phil). BSMMU. p.148.
6. Davis BG. Tools for Teaching. San Francisco: JosseyBass Publishers: 1993. Available at: http:/www josseybass.Com/. [Accessed 13 Jun 2009].

7. Rashid KM, Rahman M, Hayder S. Introduction to $\mathrm{MCH}$ care. $4^{\text {th }}$ ed. Dhaka: RHM Publishers; 2004.p.144. 